\title{
THE WAITER AT PRINCESS REATAURANT ALWAYS RESPECTS HIS GUESTS “AS A KING” TO WINNING RESTAURANT BUSINESS IN ASEAN ECONOMY COMMUNITY (AEC) ERA
}

I Wayan Pugra, Ida Ayu Ketut Sumawidari, I Ketut Redjasa. Polytechnic State of Bali

iketutredjasa@yahoo.com

\begin{abstract}
Nowadays is said to be Asean Economy Community (AEC) era. The competition on getting a job in Asean especially in Bali are getting hard and so does in restaurant business competition is getting tighter and tighter. How to winning it? The answer by Princess Restaurant's management is "Always respects his guests as "A KING" in Asean Economy Community (AEC) era.

This research is aimed to know the daily duties of waiters at Princess Restaurant if they have a specific tricks to winning restaurant business in Asean Economy Community Era.

Data of this research are obtained from informants who knows the object of the research such as The Princess Restaurant Manager, Resaturant Captains, Restaurant waiters and bus boys. After that, the data are analyzed descriptively by explaining in detail the data which has been collected to get a clearer understanding.

The result of this research showed that the daily duties of waiters at Princess Restaurant always respects his guest as "A KING" in order to winning restaurant business in AEC era.

That smart technics by waiters at Princess Restaurant could make most guest who enjoy food and drinks at Princess Restaurant feel happy and satisfied and finally could attract the guest to come again frequently as repeater guests.

This waiter's smart ways, could offer great satisfaction and nice experiences to all guests, and finally could give a positive contribution to economy, social and prosperous happiness to local people who works there.
\end{abstract}

Keywords : waiter, Princess Restaurant, As a King, winning restaurant business, Asean Economy Community.

\section{INTRODUCTION}

There's a smart service techniques which is offered by most waiters at Princess restaurant, on west Teuku Umar street no 277 Denpasar, Bali. This restaurant is located in the hearth of Denpasar city, just 25 minutes drive from Ngurah Rai International Airport.

Most waiters offers an outstanding service to all guests who come into that restaurant, because the waiter wants to respect his guest "AS A KING" in order to 
winning a restaurant business in Asean Economy Community (AEC) era.(Bulletin Princess Restaurant 2016).

What does outstanding service mean ?, the world "outstanding service" is derived from two words, I,e : word outstanding and the word service. The word outstanding means "extremely good" or so impressive. (Guswai 2015:12). Service is an uncountable noun, which mean "help and advice which is given to customers" in a shop, hotel or business. (Guswai 2015:12). If we combine those two words, would become "A service or an advice which are offered to the guests in such a business, extremely good or so impressively" (Guswai 2015:12).

By offering an outstanding service to all guests in Princess restaurant, so that the guest would feel themselves are respected as "A KING" (Bulletin Princess Restaurant 2016).

\section{STANDARD SERVICE}

If we run a such kind of business, we can fulfil the customer's needs, we say it that, we just offer a standard service. Standard means "just meet or just fulfil the customer expectations" (Guswai 2015:12).

\section{UNDER STANDARD}

Besides standard service, there is another kind of service such as under standard service. There are many shops or restaurants don't able to offer standard service which are expected by their customers. This kind of service is called "Under Standard", the service is below of the customer expectations (Guswai 2015:12).

\section{OVER STANDARD}

If there is an under standard service, there is also a business offering an extremely good service, the service which is exceeding the customer expectations, the service is so impressive. (George Ellis 1997:47).

\section{COMPETITION}

A competition is the reason "Why it is not enough to offer just a simple service to restaurant customers or a kind of service which just meet the customers expectation ?". If we serve our customers badly, but our competitors serve better, the customers will move to our competitors. Finally the outstanding service will be as a factor to differenciate our business, with our competitors.(Astina 1996:67).If you want to be different, you should be different from "Better service" (Guswai 2015:16)

\section{KEEP YOUR CUSTOMERS}

If there is a competition on restaurant business, it means that the customer has another choice to move to our competitor.

Although the competitor doesn't have a better service than ours, but still, the consumer wants to try to purchase in the new shop to experience a new experience and new service. (Rymberthus 2000:162)

If your competitor can offer a better service than yours, it will make your consumer will move permanently to your competitor.

If you don't want it would be happened, you're as the Princess restaurant staff should respect the guest as "A KING". (Bulletin Princess 2015:4). 
When your customer try to move to your competitor but your competitor can't proving that he is better in many factors, especially in service technique, so that your customer will be back again to you. (Mertayasa 2012:67). That is the powerful magic usually happens in the public to prevent the movement of our

It is proved that to respect the guest as A KING, could preserve our customer not to move, but still remain with us.

consumers, which is caused by the exist of new competitors.

(Guswai 2015:18)

\section{RESEARCH METHODOLOGY}

The research was done for 2 months full, since February $1^{\text {st }}, 2016$ until march $30^{\text {th }}, 2016$ at Princess restaurant, on west Teuku Umar street, No 277, Denpasar. The research was done twice a week, in various days and in various times. Most research was done during working hours every Mondays and Wednesdays. Sometimes the research was done during public holidays, on Saturdays and on Sundays.

I am as a researcher do the research by acting as a regular customer to have meal there in the Princess restaurant, while observing the work of the waiters in offering service to his customers.

The data which are used in this research are qualitative ones which are coming from primer data and secondary ones.

Data collecting techniques are using observation, depth interview and documentations.

Some data was got from many informants who know well about the objects which are observed, such as : the F \& B Manager, Restaurant Manager, Restaurant Captain, Waiter and Waitress.

About the methods, we used purposive method, to choose the right informant who knows well about the service quality of waiters in Princess restaurant. In order to get qualified informations and so accurate. (Sugiono 2009:48).

In order to decide respondence, we use accidental sampling technique that means to decide sample according to spontaneity factor, the respondence who was met in accidentally. (Ridwan 20017:94).

In this research we use qualitative descriptive analyses by explaining in detail the explanations which has just got from the respondence.

Finally, those informations are transformed, discussed and announced publicly to be a worthfulinformations. (Kusmayadi and Sugiarta 2001:88).

\section{RESULT AND DISCUSSION}

Service aspect are the most important one in the restaurant business in Asean Economy Community (AEC) era.

Without an outstanding service are offered to the guest in AEC era, it is similar with ship wrecked. Not so long (time) it would be sank to the bottom of the sea.

That's why, The Princess Restaurant is aware about this situation and condition of nowadays. The management of Princess Restaurant is forced all employees to respect the guest as A KING, by offering a fantastic service. 
The aims of offering a fantastic service is to offering guest satisfaction to all consumer of Princess Restaurant.

Waiter is the first liner who meet the guest for the first time and so does as the first impression that he gives to the consumers.

Because of that, the attitude, mind set, and the characteristic of waiter is the image of the whole restaurant.

The key of success of Princess Restaurant to make customer feel comfortable to be serviced, is the friendliness of waiter in serving process.

\section{GREETING THE GUEST}

When the guest comes towards Princess Restaurant, there is a pair of nice looking greeter stand by in front of main gate of the restaurant who has duty to greet the guest in warmly atmosphere, while smile naturally which means "I would be your friend".

Then this guest is escorted by a nice looking waiter to guest choice table. The waiter respect the guest as "A KING" by giving a chance freely to choose the best table for him.

\section{OFFERING FOOD}

There are ten of nice looking waiters and waitress making a line while bringing various food, starting from appetizer, main course and dessert.

One by one of waiters come towards guest while pleasing the guest to take food as much as he can. The first food is about appetizer, corn soup. The second waitress is bringing meat ball as appetizer. The third waiter is offering prawn / shrimp cocktail. The forth waitress is bringing gado-gado, mixed cooked vegetable such as : bean sprout, cabages, cucumber, long bean and peanut sauce. The fifth waiter is bringing cooked potatoes for those who has diabetes mellitus desease. The sixth waitress is bringing white rice, the main menu for Indonesian people. The seventh waiter is bringing fried rice, nice taste with bumbu Bali (sauce). The eight waitress is bringing fried chicken with bumbuasammanis. The ninth waiter is bringing some fried noodles which is garnished with acar and cucumber. The tenth waitress, the last server is bringing tropical fruits such as : melon, water melon, papaya, orange, pineapple.

By serving a complete dinner like this, the guest feel himself to be serviced as "A KING", an unforgettable experience he found in the world, just in Princess restaurant, on west Teuku Umar street, in the heart of Denpasar city.

On the buffet table, there are available many more kinds of food which can be taken by guest.

For dessert, there are available black rice pudding, fried banana with honey, jajan Bali, pancake, ice cream vanilla, chocolate ice cream, strawberry ice cream, coffee with milk, tea with lemon.

\section{ENJOYING DINNER}

On each dinning table are prepared four decorated dulang to placing the dinner plate. Dulang is an offering tool to put the offering for God. On the dulang is usually put many kinds of fruit, rice, meat, fish and decorated with sampian made of young coconut leaf, for offering. 
But the dulang which is used by restaurant guest just decorated beautifully by young coconut leave (busung), then the guest put his dinner plate on it while enjoying the meal. This kind of habit usually exist in the palace (istana) where the KING lives.

This special treatment which is applied by waiters of Princess restaurant is aimed to respect the guest as $A$ KING.

I noticed that one and the only the Princess restaurant is respecting the customer as A KING.

\section{CELEBRATING A BIRTH DAY}

One day when I did research there in Princess restaurant a guest was celebrating her birth day. Because that guest had reserved two days before, than the management of The Princess restaurant made a surprised for respecting his guest as a KING.

A big and beautiful birthday cake will be offered to the guest I that evening.

Sharp at 7 o'clock was started. There were about 10 waiter and nice looking waitress making line with lit candle on everyones, but the front waitress was bringing a big beautiful birthday cake.

When the guest who celebrate her birthday arose in front of the main gate of princess restaurant, the ten amount of waiter / waitress sang a romantic song which title was "My Sweet Heart"

It's lyrics was as follows :

Let me call you sweet heart,

I'm in love with you,

Let me hear you whisper,

That you love me too.

Keep your love light glowing

In your eyes so true

Let me call you sweet heart

I'm in love with you...uuu...

Then the waitress offer the birthday cakes to the woman with nice dress. Her husband kissed her deeply ... and followed by an original happy birthday song which was sang by all participants.

It was an unforgettable birthday celebration experienced by those party. I am as a researcher conclude that Princess restaurant always respecting his guest as A KING to winning restaurant business competition in AEC era.

\section{CONCLUSSION}

After telling a long story about the reality of Princess restaurant in winning restaurant business competition in AEC era by applying a smart strategy "Always respect his guest AS A KING".

I am as a researcher conclude that this strategy is a smart idea. The management of Princess restaurant can manage his staff to do their best for his customers.

This smart technique is so eligible to be followed by all restaurant in Bali, especially for those international restaurant in tourism cetres such as most international restaurant in Kuta, Sanur and Nusa Dua. 
This smart technique is aimed to be taught in tourism academy and also in tourism high school (SMK Pariwisata).

\section{SUGGESTIONS}

There's no ivory without cracking. That's a kind of proverb that is used in all over Indonesia, especially by Melayunese. Although the Princess restaurant has done a smart idea, an outstanding service to all his customer, let's say the service which is exceeding the guest satisfaction which is able to make his guest experiencing an unforgettable experience there in princess restaurant, but in this good opportunity I am as a researcher would like to share a little bit suggestion, positive suggestion, useful and worthfull suggestion in order to develop the service technique of the waiter of Princess restaurant for being better and better in the future.

First of all I would suggest to refresh the knowledge and skill of the waiter of Princess restaurant, because I noticed that some waiters were unfluently in speaking English with the guests when they explaining the menu.

It was happening because they have just a limit amount of vocabulary and so do their mastering English grammar is necessary to be refreshed by giving a free English course in the Princess restaurant in a sufficient time.

\section{BIBLIOGRAPHY}

Anthony M.Rey Ferdinand Wielan, 1998, Managing Service in Food and Beverage Operations, Educational Institute of the American hotel \& Motel Association, America.

Astina I nyoman Gede, Pengetahuan Bar danMinuman, STP Bali, 1996

BagusPutuSudiara, Drs. MM, 1999, Tata Boga PPLP Dhyana Pura Bali.

Budiarta I.P (2012) PariwisataAlternatif :Pariwisata Bali masa depan. (Literature Review).

Graham Brown, KaronHepner, 1996, TheWaiter's Handbook, Victoria, Australia. George Ellis 1997, Bar Attendant's Hand Book, Victoria, Australia.

Guswai :outstanding Service 2015, Penerbit PT. GramediaPustakaUtama.

Harris, rob, et al (2002) Sustainable Tourism, A Global Perspective, Oxford : Elsevier Ltd.

Mertayasa, I Gede Agus, Food \& Beverage Service Operational, Job Preparation (2012), Penerbit CV. Andi offset.

Rymbertus A AmokaraAndrikus :Pelaksanaan Standard Operation Procedure di Departemen Food and Beverage., Penerbit PT. GramediaPustakaUtama, Anggota IKAPI, Th 2000 